\title{
GENERATIONAL CONFLICT, HUMAN CAPITAL ACCUMULATION, AND ECONOMIC GROWTH
}

\author{
Douglas Holtz-Eakin \\ Mary E. Lovely \\ Mehmet S. Tosun
}

Working Paper 7762

http://www.nber.org/papers/w7762

\author{
NATIONAL BUREAU OF ECONOMIC RESEARCH \\ 1050 Massachusetts Avenue \\ Cambridge, MA 02138 \\ June 2000
}

\begin{abstract}
We are indebted to the Aging Studies Program of the Center for Policy Research at Syracuse University and the National Science Foundation for support. We thank Gerhard Glomm for helpful comments, and Esther Gray for her help in preparing the manuscript. The views expressed herein are those of the authors and not necessarily those of the National Bureau of Economic Research.

(C) 2000 by Douglas Holtz-Eakin, Mary E. Lovely, and Mehmet S. Tosun. All rights reserved. Short sections of text, not to exceed two paragraphs, may be quoted without explicit permission provided that full credit, including (C) notice, is given to the source.
\end{abstract}


Generational Conflict, Human Capital Accumulation, and Economic Growth Douglas Holtz-Eakin, Mary E. Lovely, and Mehmet S. Tosun

NBER Working Paper No. 7762

June 2000

JEL No. E62, H30, O40

\begin{abstract}
Worldwide, dependency ratios are forecast to increase dramatically in the next 50 years. A great deal of attention has been devoted to understanding the changes in fiscal policies that "must" take place to accommodate these changes. In contrast, less effort has been concentrated on studying the fiscal shifts that will endogenously result from demographic pressures. An example of particular interest is the degree to which a more elderly population will support public spending for education. We use an overlapping-generations model to investigate the effect of this demographic transition on the endogenous determination of public spending for education. A demographic transition alters the identity of the median voter, leading to a preference for less education spending. If the public sector is inefficiently small, demographic transition exacerbates the underprovision of human capital. Alternatively, such a shift may trim an inefficiently large government, reduce tax rates and raise capital per worker enough to raise education spending. Thus, there is no automatic link between demographic transition and reduced support for those programs whose benefits are concentrated among the young.
\end{abstract}

Douglas Holtz-Eakin

Department of Economics

Center for Policy Research

Syracuse University

Syracuse, NY 13244-1020

and NBER

(315) 443-9464

djheakin@maxwell.syr.edu

Mehmet S. Tosun

Department of Economics

Center for Policy Research

Syracuse University

Syracuse, NY 13244-1020

(315) 443-9044

mstosun@maxwell.syr.edu
Mary E. Lovely

Department of Economics

Syracuse University

Syracuse, NY 13244-1020

(315) 443-9048

melovely@maxwell.syr.edu 


\section{INTRODUCTION}

It is now widely understood that through a combination of lower fertility rates and longer life expectancies, most economies will "age" in the $21^{\text {st }}$ century. The old-age dependency ratio (defined as the ratio of elderly persons to non-elderly adults) is forecast to increase by 75 percent between 1990 and 2040 in the United States, by 116 percent in Germany, and by 133 percent in Japan. ${ }^{1}$ The phenomenon, however, is confined neither to the West, nor to rich countries. For example, the newly industrialized countries of Southeast Asia, which have relatively low initial dependency ratios, face a 128 percent increase in their average level of dependency.

The strain this transition will place on social security systems, and saving rates more broadly, has been well documented (for example, Cutler, et al. [1990] or Börsch-Supan [1992, 1996]). In these studies, the neoclassical growth model is used to illustrate the "necessary" changes in saving and growth that policymakers should contemplate to address the demographic transition. $^{2}$

However, demographic transition itself will likely alter public support for government programs, and thus endogenously alter fiscal policy. It is surprising that the implications of an aging population for publicly provided goods and services have received less attention. ${ }^{3}$ Recent research has emphasized the important role of human capital in economic growth (see, e.g., Mankiw et al. [1992]), the accumulation of which depends in part on public spending and taxing decisions. $^{4}$ If the elderly do not support programs from which they do not directly benefit, it raises the possibility that demographic transition may undermine the level of public spending for a productivity-enhancing social infrastructure and, hence, harm long-run economic welfare.

Our goal is to examine the link between aging populations, old-age preferences for public programs, and economic performance. To focus squarely on the role of endogenous spending 
and the impact of aging, we base our analysis on a standard overlapping-generations model of economic growth. We use a simple median voter framework to represent the political process. In this context, a slowdown in the population growth rate raises the average age of the population and alters the level of public spending on education. The resultant change in the level of human capital affects the level of per-capita income.

The next section presents our modeling strategy and the derivation of individuals' policy preferences. The third section describes the political process and the outcome of majority voting. In the fourth section, we characterize the equilibrium and trace the evolution of the economy. Next we investigate the effects of demographic transitions on steady states in the model. In the sixth section, we simulate the steady-state effects; the seventh section presents simulations of the transitional dynamics. The final section contains concluding comments and suggestions for further research.

\section{MODELING STRATEGY AND POLICY PREFERENCES}

We base our analysis on a conventional overlapping-generations model (Diamond [1965]) in which individuals live for two periods. Each period, a cohort of size $N_{t}$ is born, where $N_{t}=(1+\eta) N_{t-1}$. The population at any point consists of the "old" and the "young" and, thus, is of size $N_{t}+N_{t-1}$. Note that $\eta$ determines both the growth rate of the total population and the ratio of old to young, which equals $\frac{1}{1+\eta}$. Demographic transition is introduced as a decrease in $\eta$ that raises the dependency ratio.

We focus our discussion of fiscal policy on a single type of government spending financed by a flat income tax on the labor income of the young and the capital income of the old. 
To highlight the possibility for generational conflict, we posit that the public good enhances the productivity of labor. There is no consumption demand for the public good per se; demand derives solely from its effect on the income of the young. Moreover, there are no deliberate transfers from the old to the young or vice versa. With these modeling choices, there is no gain in utility for the currently old cohort from the provision of public services to the young and generational conflict is maximized. ${ }^{5}$

The conventional overlapping-generations framework provides a rather sterile theory of public choice: the young will all want the same, positive level of the publicly provided good while the old will want none. A median-voter representation of the political process leads to a simple counting of generational size. With positive population growth, the young will always outnumber the old, the young will always determine the political outcome, and (because the young are identical), there will be a single level of human capital.

To address these shortcomings, we posit a distribution of abilities within each generation. ${ }^{6}$ The ability of individuals ranges from 0 to 1 , and the density function of abilities for each generation is denoted by $f(a)$. By definition, the density function satisfies $\int_{0}^{1} f(a) d a=1$. As described below, high-ability individuals benefit more (acquire more human capital) from a given amount of government spending than do low-ability individuals. Thus, the economy will display a distribution of human capital and income. For this reason, the distribution of ability leads to a distribution of preferred spending levels. ${ }^{7}$

Turning to specifics, each individual is assumed to have a lifetime utility function given by:

$$
U=\ln C_{j t}+\left[\frac{1}{1+\delta}\right] \ln C_{j t+1}
$$


where $C_{j t}$ is consumption of a member of generation $j$ when young, $C_{j t+1}$ is consumption when old, and $\delta$ is the pure rate of time preference. When young, the individual supplies one unit of "time" to the economy. However, effective labor units are measured by the human capital of the individual, $h_{t}\left(a_{i}\right)$, where $a_{i}$ denotes the ability level of individual $i{ }^{8}$ Labor income is thus $w_{t} h_{t}\left(a_{i}\right)$, where $w_{t}$ is the wage at time $t$. The individual pays taxes on labor income and capital income at the rate $\tau_{t}$. Given these arrangements, the young person of ability $a_{i}$ is faced with a budget constraint of the form:

$$
C_{j t}\left(a_{i}\right)+S_{j t}\left(a_{i}\right)=\theta_{t} w_{t} h_{t}\left(a_{i}\right)
$$

where $\theta_{t}=\left(1-\tau_{t}\right)$ and $S_{j t}$ is first-period saving. Old-age consumption is financed by saving:

$$
C_{j t+1}\left(a_{i}\right)=\left(1+r_{t+1} \theta_{t+1}\right) S_{j t}\left(a_{i}\right)
$$

where $r_{t+1}$ is the return to capital in the economy. Human capital acquisition depends on the interaction of each individual's ability and expenditures by the government on a productive input into the human capital accumulation process (hereafter "education spending"). The production function for human capital shows the dependence of human capital acquired on the interaction of ability and educational spending:

$$
h_{t}\left(a_{i}\right)=A_{H}\left[a_{i} g_{t}+1\right]^{\psi}
$$

where $h_{t}\left(a_{i}\right)$ is the human capital acquired by a person of ability level $a_{i}$ when provided with $g_{t}$ of education spending per young person. ${ }^{9}$ To rule out increasing returns in public service provision, we restrict the value of $\psi$ to be less than unity. The form of (4) ensures that individuals of the lowest ability $\left(a_{i}=0\right)$ provide some productive labor to the economy and that higher ability individuals provide an amount dependent on their own ability level and $g_{t}$. 
The young maximize (1) subject to (2), (3), and (4). Taking $g_{t}$ as given, the first order condition for the choice of $C_{j t}$ is:

$$
C_{j t}\left(a_{i}\right)=\left[\frac{1}{1+\delta}\right] S_{j t}\left(a_{i}\right)
$$

Using equation (5) and the budget constraint, the optimal saving of a young person in generation $j$ is given by:

$$
S_{j t}\left(a_{i}\right)=\left[\frac{1}{2+\delta}\right] \theta_{t} w_{t} h_{t}\left(a_{i}\right),
$$

which does not depend on fiscal policy in future periods. ${ }^{10}$ Corresponding to the saving function are the consumption functions:

$$
\begin{aligned}
& C_{j t}\left(a_{i}\right)=\left[\frac{1+\delta}{2+\delta}\right] \theta_{t} w_{t} h_{t}\left(a_{i}\right) ; \\
& C_{j t+1}\left(a_{i}\right)=\left[\frac{1}{2+\delta}\right]\left[\frac{\theta_{t} w_{t} h_{t}\left(a_{i}\right)}{1+r_{t+1} \theta_{t+1}}\right] .
\end{aligned}
$$

Thus far, fiscal policy has been taken as given. However, each member of the young generation will have a preferred policy mix that balances the benefits of spending with the taxassociated costs. To characterize this preferred policy, we substitute the consumption functions (7) and (8) into the utility function (1), yielding the indirect utility function

$$
\begin{aligned}
V_{t}\left(a_{i}\right)= & \ln (1+\delta)-\frac{2+\delta}{1+\delta} \ln (2+\delta)+\frac{2+\delta}{1+\delta}\left[\ln \theta_{t}+\ln w_{t}+\ln h_{t}\left(a_{i}\right)\right] \\
& -\frac{1}{1+\delta} \ln \left(1+r_{t+1} \theta_{t+1}\right) .
\end{aligned}
$$

We assume that each voter views himself as small relative to the economy, and thus takes $w_{t}, r_{t+1}$, and $\theta_{t+1}$ as given. As a result, the preferred value of $\tau_{t}$ will maximize current after-tax 
income, subject to the government budget constraint, $\tau_{t} y_{t}=g_{t}$, where $y_{t}$ is income per young person, which is also taken as given by an individual voter. This preferred tax rate is

$$
\tau_{j t}\left(a_{i}\right)=\frac{a_{i} \psi y_{t}-1}{(1+\psi) a_{i} y_{t}}
$$

Note that the preferred tax rate depends directly only upon the current level of aggregate income

per worker and the individual's ability. ${ }^{11}$ It is straightforward to verify that $\tau_{j t}\left(a_{i}\right)$ is increasing in $a_{i}$. Also, higher-ability individuals will have higher individual incomes. In addition, higherability individuals receive a disproportionately higher marginal value of additional spending. Combining these two effects, (10) implies a positive income elasticity for the preferred tax rate. Decision making by the old is trivial. Since they receive no benefits but face taxes on capital income from their first-period saving, every member of the old generation has the same preferred tax rate of

$$
\tau_{j-1, t}=0
$$

\section{THE POLITICAL PROCESS}

Following a long tradition dating to Black [1948], we adopt a median-voter approach to public choice. The median-voter model is appropriate in the context of our model for several reasons. First, the choice facing voters is over a single dimension and voters' preferences have a single peak. Thus, it is possible to define a median voter. Second, in the context of the overlapping generations model, our use of the median voter model effectively asserts only that over relatively long periods the public sector is responsive to voter preferences. It need not rule out short-run rigidities, bureaucratic agency problems, or monopoly power that are important aspects of criticisms of the median-voter model. ${ }^{12}$ 
The median voter is that whose preferred tax and spending policy would win a majority of votes against any other feasible alternative. To win a majority, a proposed fiscal combination must achieve votes equal to $\left(N_{t-1}+N_{t}\right) / 2$. Because the preferred tax rate of the old is zero, there will be $N_{t-1}$ voters who will always prefer the smaller of two proposed tax rates. Among the young, those with lesser ability prefer a lower tax rate than those with greater ability. Thus, the median voter, denoted by her ability level $a_{m}$, is defined by

$$
N_{t-1}+N_{t} \int_{0}^{a_{m}} f(a) d a=\frac{N_{t-1}+N_{t}}{2} .
$$

Given a value for $a_{m}$, the actual budget and spending policies of the economy may be calculated using (10) and the government budget constraint. The tax and spending values that determine consumption, saving, and human capital accumulation are those of the median voter.

\section{PRODUCTION, EQUILIBRIUM AND DYNAMICS}

Total output in the economy is governed by the production function

$$
Y_{t}=A_{Y} K_{t}^{\alpha} H_{t}^{1-\alpha}
$$

Human capital depends on education spending and the distribution of ability. The aggregate supply of human capital is defined as

$$
H_{t}=N_{t} \int_{0}^{1} h(a) f(a) d a .
$$

Using (4), human capital per young person is

$$
h_{t}=A_{H} \int_{0}^{1}\left[a g_{t}+1\right]^{\psi} f(a) d a \text {. }
$$


where lower-case quantities are per young person, i.e., $k_{t}=K_{t} / N_{t}$ and $h_{t}=H_{t} / N_{t}$. Given

levels of human capital, labor is supplied inelastically and the labor market clears when the wage is equal to the marginal product of labor:

$$
w_{t}=(1-\alpha) A_{Y}\left[\frac{k_{t}}{h_{t}}\right]^{\alpha}
$$

Similarly, equilibrium in the market for capital inputs occurs when the real rental price of capital equals the marginal product of capital:

$$
r_{t}=\alpha A_{Y}\left[\frac{k_{t}}{h_{t}}\right]^{\alpha-1}
$$

Because of differences in human capital within a generation, supplies of capital (saving) differ across individuals. Aggregating individual saving (6) using the human capital supply function (15), saving per young person is:

$$
s_{t}=\left(\frac{1}{2}\right)\left(\frac{1}{2+\delta}\right) \theta_{t} w_{t} A_{H} \int_{0}^{1}\left[a g_{t}+1\right]^{\psi} f(a) d a
$$

Capital market equilibrium requires:

$$
k_{t+1}=\frac{s_{t}}{1+\eta}
$$

Combining (18) and (19), capital per young person evolves according to: ${ }^{13}$

$$
k_{t+1}=\left[\frac{1}{2(1+\eta)}\right]\left[\frac{1}{2+\delta}\right] \theta_{t} w_{t} A_{H} \int_{0}^{1}\left[a g_{t}+1\right]^{\psi} f(a) d a .
$$

As can be seen directly from equation (20), fiscal policy choices $\left(\theta_{t}, g_{t}\right)$ have an important influence on the evolution of capital in the economy. Moreover, the evolution of the economy itself affects the adopted tax policy, as equation (10) shows that the preferred tax rate of any individual depends on income per person. These dynamics are potentially quite complicated, but our choice of logarithmic preferences makes it possible to describe analytically the effects of 
population aging on the steady state of the economy. Once we have examined these steady-state effects, we use numerical simulations to gauge the sensitivity of our steady-state analysis to different values for several key parameters. We also employ numerical simulations to trace out the transition path between steady states that results from a rise in the dependency ratio.

\section{STEADY STATE IMPLICATIONS OF DEMOGRAPHIC TRANSITION}

As in the conventional overlapping generations model, the steady state is characterized by $k_{t+1}=k_{t}$. It is straightforward to verify that this equality simultaneously implies constant values for human capital per worker, income per worker, education spending per young person, preferred tax rate of the median voter, and ability of the median voter. The steady state will be disrupted by a demographic transition, i.e., by a decrease in $\eta$. To see how a decrease in $\eta$ alters the steady state, we begin by differentiating (12) to show that the ability of the median voter will fall:

$$
\frac{d a_{m}}{d \eta}=\frac{1}{2} \frac{1}{(1+\eta)^{2}} \frac{1}{F^{\prime}\left(a_{m}\right)}>0 .
$$

The location of the median voter in the ability distribution changes because when $\eta$ decreases the number of old people relative to the number of young people rises. With relatively more old voters, a majority can be formed with fewer young voters. The median voter becomes a person with a lower ability. Note that as a consequence, the median voter's preferred tax rate will immediately be lower, even at the income level of the initial steady state.

To pursue further analytic solutions for the effect of a decrease in $\eta$ on the steady state of the economy, we are forced to choose a specific distribution for ability. Thus, we assume that ability among the young follows a uniform distribution. While the uniform distribution is

special, the key insights of the model do not depend on it. As we have just shown, a decrease in 
the population growth rate creates a median voter with a lower ability. Therefore, regardless of the ability distribution, the tax rate chosen (at any given average income level) will be lower when the population grows more slowly. It is this reduction in desired tax rates, rather than the specific ability distribution, that produces our key results.

\subsection{Steady-State Comparisons}

The condition for capital market equilibrium holds in both the initial and the post-

transition steady state. Noting that $k_{t}=k_{t+1}$ in the steady state and denoting steady-state values by the absence of time subscripts, total differentiation of (19) yields,

$$
\hat{k}=\hat{s}-(\widehat{1+\eta}),
$$

where $\hat{x}=d x / x$ indicates the proportionate change in a steady-state value. Saving per young person is given by (18), which can be totally differentiated to yield

$$
\hat{s}=\widehat{w}+\hat{h}-\Delta \hat{\tau}
$$

where $\Delta=\tau /(1-\tau)$. The change in human capital depends on the adjustment in steady-state education spending. Recalling our assumption that the ability distribution follows a uniform distribution, and integrating (15), human capital per worker is

$$
h_{t}=\frac{A_{H}}{(\psi+1) g_{m t}}\left[\left(1+g_{m t}\right)^{\psi-1}-1\right] \text {, }
$$

where $g_{m t}$ is the level of spending preferred by the median voter at time $t$. Totally differentiating and evaluating at the steady-state,

$$
\hat{h}=\varepsilon_{h g} \hat{g}_{m}
$$


where $\varepsilon_{h g}$ is the elasticity of human capital per worker with respect to government education spending. ${ }^{14}$ Government budget balance restricts the change in the steady-state level of spending:

$$
\hat{g}_{m}=\hat{\tau}_{m}+\hat{y}
$$

The change in steady-state spending must also conform to the new political equilibrium.

Differentiating the expression for the median voter's preferred tax rate (10),

$$
\hat{\tau}_{m}=\varepsilon_{\tau a} \hat{a}_{m}+\varepsilon_{\tau y} \hat{y}
$$

where the elasticities of the preferred tax rate with respect to ability and income are:

$$
\varepsilon_{\tau a}=\varepsilon_{\tau y}=\frac{1}{a_{m} \psi y-1},
$$

and these elasticities are positive for positive $\tau$. Finally, turning to steady-state production, differentiation of (13) yields

$$
\hat{y}=\alpha \hat{k}+(1-\alpha) \widehat{h}
$$

The change in the wage also depends on adjustments to physical and human capital; using (16),

$$
\widehat{w}=\alpha(\hat{k}-\hat{h})
$$

\subsection{Demographic Transition Without Endogenous Politics}

Since we wish to highlight the importance of endogenous policy, it is useful to establish as a baseline the effect of demographic transition without politics. Thus, we begin by deriving the effect of a change in $\eta$ on the steady-state capital stock and income, assuming that the level of education spending per young person remains fixed. ${ }^{15}$

Because $g$ is fixed, the level of human capital is fixed. Consequently,

$$
\hat{y}=\alpha \hat{k}
$$


Also, by assumption, the tax rate is affected only by income changes that make it easier or harder to finance $g$ :

$$
\hat{\tau}=-\hat{y}
$$

Noting that wages grow at the same rate as income, and using (22), (23), (31) and (32),

$$
\hat{k}=-\frac{1}{1-\alpha(1+\Delta)}(\widehat{1+\eta}) .
$$

Stability of the intertemporal equilibrium requires $1>\alpha(1-\Delta)$ so a decrease in $\eta$ leads the economy to a steady state with a higher level of capital per worker. ${ }^{16}$ In keeping with this result, steady-state income per young person, consumption, and the wage also rise.

That a decrease in population growth raises steady-state income per worker is a wellknown result from the conventional neoclassical growth model. Lower population growth reduces break-even investment, the amount of investment necessary to keep $k$ constant, without affecting saving at any given level of capital. Public finance matters only in that the tax rate affects the slope of the saving function.

\subsection{Demographic Transition With Endogenous Politics}

Recognizing an individual's political incentives broadens the effect of demographic transition to encompass tax rate changes for reasons other than those due to national income. Slower population growth reduces the tax rate preferred by the median voter, ceteris paribus, leading to changes in government outlays and human capital. Feedbacks via physical capital will, in turn, further influence the political equilibrium.

Changes in the steady-state capital per worker derive from changes in after-tax income and changes in the number of workers. Using (22) and (23),

$$
\hat{k}=\hat{w}+\hat{h}-\Delta \hat{\tau}-(\widehat{1+\eta})
$$


Substituting using equations (25) to (27), and (29) and (30) yields the quasi-reduced form expression,

$$
\hat{k}=\frac{\left((1-\alpha) \varepsilon_{h g}-\tau\right) M_{K}}{1-\tau} \varepsilon_{\tau \alpha} \widehat{a_{m}}-\frac{M_{K}}{M_{Y}}(\widehat{1+\eta}),
$$

where

$$
\begin{aligned}
& M_{Y}=\frac{1}{1-(1-\alpha) \varepsilon_{h g}\left(1+\varepsilon_{\tau y}\right)}, \text { and } \\
& M_{K}=\frac{1}{(1-\alpha)\left(1-\varepsilon_{h g}\left(1+\varepsilon_{\tau y}\right)\right)+\alpha \Delta \varepsilon_{t y}}
\end{aligned}
$$

Local stability of the political equilibrium requires $M_{Y}>0$ while local stability of the intertemporal equilibrium requires $M_{K}>0 .{ }^{17}$

To gain a feel for the importance of endogenous political responses, consider first the case in which the ability of the median voter, $a_{m}$, is fixed, but government spending is not. That is, due to changes in the economic steady state, the same pivotal voter alters the demand for government spending. Looking at the second term on the right side of (35), we see that a decrease in population growth raises steady-state capital per worker, holding $a_{m}$ fixed. ${ }^{18}$ What determines this effect? $M_{Y}$ is the multiplier effect of an autonomous increase in output (say due to a productivity change or shift in $A_{Y}$ ) on steady state output, while $M_{K}$ is the corresponding multiplier effect of a windfall of capital on steady-state capital per worker.

Consequently, the coefficient on $(\widehat{1+\eta})$ in $(35)$ is the effect of an initial increase in capital per worker (due to a decrease in the size of the working population) on income and the effect of this rise in income on capital accumulation. ${ }^{19}$ 
As noted above, however, a decrease in $\eta$ changes the identity of the median voter to that of a lower ability person. This voter-identity effect has an indeterminant influence on steadystate capital per worker, as can be verified by looking at the coefficient on $\widehat{a_{m}}$ in (35).

To see why the effect is ambiguous, consider a social planner who is constrained to offer the same amount of education to everyone, regardless of ability. This constrained social optimum is characterized by the first order condition

$$
(1-\alpha) \varepsilon_{h g}=\tau
$$

The planner chooses a level of education spending that equates the marginal benefit of education, measured as its proportionate impact on income, $(1-\alpha) \varepsilon_{h g}$, with its marginal cost, also measured as its proportionate impact on income, $\tau$. The coefficient on $a_{m}$ can be interpreted in this light. If the median voter initially chooses spending on education that is "too high," the coefficient will be negative, and a reduction in the median voter's ability will raise capital per worker in the steady state. Effectively, the shift in $a_{m}$ cuts back on inefficient spending-that whose marginal contribution to total income is less than its marginal cost in terms of lost consumption. On the other hand, if spending is initially "too low," the decrease in the median voter's ability exacerbates the inefficiency, reducing income, saving, and capital per worker in the steady state.

The median voter's choice can be compared to the social planner's choice by noting that the median voter chooses $\tau$ to maximize her after-tax income. The first-order condition guiding the median voter can be expressed as

$$
(1-\tau) \varepsilon_{h g}^{m}=\tau
$$

where $\varepsilon_{h g}^{m}$ is the elasticity of the median voter's human capital with respect to education spending. In comparing this condition to (36), we notice two differences. First, the planner chooses public spending to maximize national income rather than after-tax income. Secondly, 
the average effectiveness of education in raising human capital, $\varepsilon_{h g}$, differs from its impact on the median voter, $\varepsilon_{h g}^{m}$. Indeed, if ability is distributed uniformly, the marginal impact of education on the median voter's human capital is less than its average marginal impact. Taken together, these differences imply that the political equilibrium may provide too much or too little education spending and demographic transition may reduce or increase capital per worker.

Even if capital per worker is higher in the new steady-state, however, there is no assurance that income per worker will rise. This indeterminancy results from the possibility that human capital per worker falls when a lower tax rate is chosen. A useful reduced form expression for the change in education spending is:

$$
\hat{g}=M_{Y}\left[\varepsilon_{\tau a} \hat{a}_{m}+\alpha\left(1+\varepsilon_{\tau y}\right) \hat{k}\right]
$$

Because $\varepsilon_{\tau a}$ is positive, as is $M_{Y}$, a reduction in the median voter's ability may result in lower steady-state government spending despite an increase in capital per worker. Consequently, human capital per worker may fall and the economy's human-to-physical capital ratio may fall. The change in steady-state income per worker depends on the change in $h$ and $k$, and may be expressed as:

$$
\hat{y}=M_{Y}\left[(1-\alpha) \varepsilon_{h g} \varepsilon_{\tau a} \widehat{a_{m}}+\alpha \hat{k}\right]
$$

The coefficient on $\widehat{a_{m}}$ is positive, so a fall in the median voter's ability may reduce income even when it raises steady-state capital per worker. This immiserizing outcome is more likely to occur, for a given $\hat{k}$, the larger are the elasticities $\varepsilon_{h g}$ and $\varepsilon_{\tau a}$ and the larger is labor's share of national income, $(1-\alpha)$. It can be shown that $\varepsilon_{\tau a}$, the response of the preferred tax rate to a change in ability, is smaller the larger is $\psi$. Ceteris paribus, the more effective public education 
is in raising human capital (defined as larger $\psi$ ), the smaller the decrease in the equilibrium tax rate resulting from the demographic transition.

A more effective education system, however, also implies a larger loss in human capital as a result of the decrease in $\tau$ precipitated solely by the fall in voter ability. The elasticity $\varepsilon_{h g}$ is larger for a larger $\psi$, so holding $\varepsilon_{\tau a}$ constant, a larger $\psi$ makes it more likely that a decline in the population growth rate is immiserizing.

Labor's share of national income also determines the income loss from a shift in the median voter. The larger this share is, the more a decrease in human capital reduces national income. In simulations described below, we characterize the combinations of $\alpha$ and $\psi$ that produce an immiserizing outcome.

\section{SIMULATION METHODS AND STEADY-STATE SENSITIVITES}

To better understand the implications of the model, we use numerical simulations to gauge the sensitivity of our steady-state analysis to values for key parameters. We also undertake a series of numerical simulations to investigate the dynamics of transition between steady states. A necessary price of doing so, however, is that we must adopt specific functional forms and parameters for our model.

To begin, we set $\delta$ equivalent to an annual rate of time preference of 4 percent. $^{20}$ Under the crude assumption that one "period" in the model equals 30 years, the 4 percent rate of time preference translates into a value of $\delta$ equal to $(1.04)^{30}-1=2.24$. Alternatively, $1 /(1.04)^{30}=0.308$ is the rate at which the future is discounted in the model.

We begin with the assumption that the population growth rate $(\eta)$ is 2.0 percent annually, a bit more rapid than the recent United States experience. This annual rate corresponds to growth of 81.1 percent over a model period. In the context of the model, $\eta$ serves as well as 
the key parameter for analyzing generational shifts. The ratio of the old to young generations is given by $1 /(1+\eta)$; in our base case, this is equal to 0.55 . We investigate the dynamics resulting from a shift in the population growth rate from 2.0 percent (annually) to 1.0 percent. Thus, in the model the dependency ratio rises to 0.74 , an increase of roughly 35 percent. We assume that ability, $a$, is distributed uniformly in the interval $[0,1] .{ }^{21}$ Finally, we set the elasticity of output with respect to capital input equal to one-third $(\alpha=0.33){ }^{22}$

We do not constrain ourselves to a particular value of $\psi$. Instead, Table 1 summarizes our comparative steady-state results for a range of values for $\psi$, the elasticity of human capital output with respect to inputs of ability and government spending. Entries in the first column serve as our "exogenous policy" baseline. They are derived by holding government spending fixed when the population growth rate is reduced. Looking at the results, the tax rate always declines, capital per worker always grows, and income always grows regardless of the value chosen for $\psi$. The decline in the tax rate varies only slightly as $\psi$ increases, reflecting only $\psi$ 's effect on average income.

In contrast, consider column (2) in which government spending is determined by a median voter. Here, a larger value for $\psi$ has a direct effect on the desired amount of government spending. The tax rate falls dramatically for low values of $\psi$, but actually falls by less than the exogenous policy case for high values of $\psi$. Indeed, for high enough $\psi$, as shown by the results for $\psi=0.5$, government spending and human capital actually rise even though the tax rate falls. At lower values of $\psi$, steady-state capital per worker and income per worker rise even though human capital falls. For the value $\psi=0.32$ (and below), however, the decline in human capital is so severe that income per worker declines even though capital increases. The low $\psi$ value implies a large $\varepsilon_{\tau a}$ and, thus, a large decline in government spending when the 
ability of the median voter falls. This case illustrates the possibility of immiserizing

demographic transition stemming from the endogenous response of public spending. ${ }^{23}$

The critical value of $\psi$, above which income per worker rises, depends on the share of labor income in national income $(1-\alpha)$. In Figure 1 , for a range of values for $\alpha$, we trace out the critical value of $\psi$ above which a decline in the population growth rate raises income per worker. This relationship is non-linear in general, but for $\alpha>0.33$ the value of $\psi$ needed to ensure income growth is increasing in $\alpha$ values. ${ }^{24}$ This relationship reflects the lower income payoff from additional government spending when labor's share $(1-\alpha)$ is low and thus the need for a smaller human capital response from the decline in median voter ability to prevent an immiserizing outcome.

\section{TRANSITION PATHS}

Of course, comparative steady states may provide a misleading picture of the actual events that transpire during the process of demographic shift. To shed light on the dynamics, Figures 2 through 5 depict the transition paths obtaining for a case in which the demographic transition leads to higher steady-state income, specifically for $\psi=0.5{ }^{25}$

Figure 2 translates the political logic of steady states directly to the transition period. In response to the shift, the ability level of the median voter declines and remains unchanged. The level of spending preferred by the median voter, however, initially declines but rises gradually as income per worker rises. Indeed, eventually education spending is higher than in the case of a fixed level of government spending. As shown in Figure 3, the level of human capital per worker mimics this pattern, dropping precipitously in the first period and rising so that it exceeds the fixed- $g$ case. The dynamic path of human capital follows from the rapid growth in economic activity (Figure 4) generated by accumulation of physical (Figure 5) capital. Thus, while we find 
poorer economic performance during the very early periods of transition, the model suggests that endogenous formulation of fiscal policy may provide for a compensating boost in growth that raises income per worker. As we discussed above, however, the long-run effect of the population shift depends on both the value of $\psi$ (the effectiveness of government spending in raising productivity) and on the degree to which the initial conditions are characterized by an inefficiently large (or small) public sector.

\section{CONCLUSIONS}

As dependency ratios increase over the next 50 years there will be corresponding shifts in the political pressures that determine fiscal policy. Because of the key role of human capital in economic performance, the degree to which a more elderly population will support public spending for education is of particular interest. In the context of a median-voter model of the political process, embedded within an overlapping-generations model of economic growth, we have show that there is no automatic link between the preference for lower education spending by older individuals and the long-run provision of human capital to young workers. Instead, when the demographic transition alters the identity of the median voter, if the public sector is inefficiently small, the resultant political and economic dynamics will exacerbate the underprovision of human capital However, it is also possible that such a shift may trim an inefficiently large government, reduce tax rates and raise capital per worker enough to raise the long-run level of education spending per worker.

Our findings highlight the importance of three issues for future research. First, a key parameter in our model is the mapping between educational inputs and the production of human capital, making clear the value of additional research in this area. Second, our model focuses on the provision of public education spending at the expense of a detailed description of the 
financing structure. To the extent that non-neutral income taxes and other financing schemes alter the incentives to acquire human capital, it would be useful to embody these effects in future research. Finally, our results are derived in the context of a closed economy. In the presence of internationally mobile capital, two additional features may be important. To begin, capital will flow internationally in pursuit of the highest return, altering the dynamics of capital accumulation. However, the simultaneous aging of other counties will induce political pressures for altered fiscal policies and capital flows across the globe. 


\section{APPENDIX: STABILITY ANALYSIS}

\section{STABILITY OF THE POLITICAL EQUILIBRIUM}

Analysis of the stability of the political equilibrium obtaining in any given period allows us to sign the term $M_{Y}$ in the text. The political equilibrium is defined to be locally stable if, starting from a given level of $g$, the economy moves automatically to an equilibrium. To analyze stability, we posit a Marshallian-type adjustment rule for government spending of the form

$$
\dot{g}=c\left[\frac{\tau_{p}}{\tau}-1\right]=\varphi(g)
$$

where the $c$ is a positive constant and the dot above a variable represents its time derivative. The variable $\tau$ is the actual tax rate, as necessitated by the government budget constraint. It is a function of $g$ and the contemporary level of income per young person. The variable $\tau_{p}$ is the tax rate desired by the median voter at the given level of education spending and income. The rationale behind (A.1) is that education spending will increase if the desired tax rate exceeds the actual tax rate needed to balance the government's budget. The equilibrium level of spending, $\bar{g}$ solves $\varphi(\bar{g})=0 . \quad \bar{g}$ is locally dynamically stable if and only if $\varphi^{\prime}(\bar{g})<0$.

Using (25), (27), and (29) and noting that within a generational period the capital stock is given,

$$
\hat{\tau}_{p}=(1-\alpha) \varepsilon_{h g} \varepsilon_{\tau y} \hat{g}
$$

where the elasticities are defined in the text and $\hat{x}$ is defined as $\dot{x} / x$. Rearranging the differentiated government budget constraint and using (25) and (29), the actual tax rate changes according to:

$$
\hat{\tau}=\left[1-(1-\alpha) \varepsilon_{h g}\right] \hat{g}
$$


Differentiating (A.1) and using (A.2) and (A.3), stability of the political equilibrium requires that

$$
\varphi^{\prime}(g)=(1-\alpha) \varepsilon_{h g}\left(1+\varepsilon_{\tau y}\right)-1<0 .
$$

Condition (A.4) implies that $M_{Y}$, as defined in the text, is positive if the within-generation political equilibrium is stable.

\section{INTERTEMPORAL STABILITY WITH ENDOGENOUS POLITICS}

With Cobb-Douglas production technology and logarithmic preferences, the evolution of the capital stock is a function of the contemporaneous tax rate, wage, and human capital level. Since the tax rate, wage, and human capital level are functions of the contemporaneous capital stock, the evolution of the capital stock takes the form:

$$
k_{t+1}=G\left(k_{t}\right)
$$

A sufficient condition for a locally dynamically stable steady state is that $G^{\prime}(k)<1$ when evaluated at the steady state value of $k_{.}{ }^{26}$ Using (22) and (23),

$$
\hat{k}_{t+1}=\hat{w}_{t}+\hat{h}_{t}+\Delta \hat{\tau}_{t}
$$

where $\hat{x}$ indicates $\dot{x} / x$. Substituting by using (25), (27), (29) and (30), letting $\hat{\eta}=0$, and evaluating at the steady state,

$$
G^{\prime}(k)=\alpha\left(1-\Delta \varepsilon_{\tau y}\right) M_{Y}
$$

where $M_{Y}$ is defined in the text and is positive because we assume a stable political equilibrium. Using (A.7), the definition of $M_{Y}$, and rearranging, stability implies

$$
(1-\alpha)\left(1-\varepsilon_{h g}\left(1+\varepsilon_{\tau y}\right)\right)+\alpha \Delta \varepsilon_{\tau y}>0
$$

Therefore, if the economy exhibits intertemporal stability, the expression defined as $M_{K}$ in the text is positive. 


\section{INTERTEMPORAL STABILITY WITH FIXED GOVERNMENT SPENDING}

With $g$ fixed, using (23)

$$
\hat{k}_{t+1}=\hat{w}_{t}+\Delta \hat{\tau}_{t} .
$$

Using (32) and the fact that wages grow at the same rate as income,

$$
\hat{k}_{t+1}=\alpha \hat{k}_{t}-\Delta \alpha \hat{k}_{t}=\alpha(1-\Delta) \hat{k}_{t} .
$$

Stability requires $G^{\prime}\left(k_{t}\right)<1$ when evaluated at the steady state. Consequently, stability requires

$$
\alpha(1-\Delta)<1 .
$$

This permits us to sign the denominator of (33) when the economy exhibits intertemporal stability. 


\section{ENDNOTES}

1. See Börsch-Supan [1995].

2. Another strand of the literature looks at how different institutional arrangements alter the impact of population aging. Brueckner [1999], for example, studies the choice of fiscal federalism versus unitary government for long-run capital intensity and growth.

3. A related literature investigates the effect of one form of endogenous policy, redistributive taxation, on growth (an extensive survey of which is provided by Persson and Tabellini [1994]). A contrasting approach is taken by Wright [1996], who studies the effect of changes in an exogenous growth rate on fiscal choices. Wright suggests that the complex feedback between policy and growth may explain the conflicting results of the empirical literature, which contains instances of both positive and negative correlations between cross-country growth rates and government policy variables.

4. Our focus is on the provision decision. Alternatively, Bovenberg and vanEwijk [1997] study the impact of progressive taxation on human capital accumulation and long-run growth.

5. Notice that despite our use of the term "dependency ratio," our model does not contain explicit provision of old-age consumption via government programs (e.g., Social Security). Meijdam and Verbon [1996], in contrast, analyze the effect of aging on the political decision making for public pensions in an overlapping-generations model. As in the current paper, they find that with growth an increase in the political power of the old may not alter fiscal choices in the direction expected in the absence of growth. Kaganovich and Zilcha [1999] study the effect of various allocations of tax revenues to education and social security benefits on growth. Their model does not, however, permit this allocation to be endogenously determined.

6. We assume that the distribution of abilities is the same in all generations so as not to confound the effect of changes in size of generations (demographic shift) with changes in the composition of generations.

7. Holtz-Eakin [1993], in an overlapping-generations framework, obtains a distribution of preferences for a publicly provided good by introducing the possibility that not all individuals born at time $t$ survive to time $t+1$. This assumption generates "accidental bequests" inherited by members of the next generation and induces a distribution of incomes within the younger generation.

8. In the context of our model, allowing an endogenous allocation of time between "schooling" and supplying labor does not change our analysis. All young workers, regardless of ability, will choose to allocate the same proportion of time to supplying labor. 
9. We assume education services are equally distributed among all ability types, as in Epple and Romano [1996]. Equal division introduces a distortion in that the marginal product of educational services are not equalized across young people of different abilities.

10. This is a direct result of our choice of logarithmic utility, and greatly simplifies the analytics. We relax this restriction in our simulation analysis.

11. It is useful to note that the solution for the preferred tax rate is the same for all utility functions of the constant relative risk-aversion form. In particular, our solution is not specific to logarithmic preferences.

12. See Romer and Rosenthal [1983] for an overview of the model's uses and limitations.

13. In a related model, Glomm and Ravikumar [1995] show that the overlapping-generations model may yield multiple equilibria. Our choice of utility function eliminates this possibility.

14. Given the form (4) for the relationship between human capital and educational spending,

$$
\varepsilon_{h g}=\frac{1}{\left[\left(1+g_{m}\right)^{\psi+1}-1\right]}\left[\left(\psi g_{m}-1\right)\left(1+g_{m}\right)^{\psi}+1\right] \text {. }
$$

15. Alternatively, we could fix the tax rate. However, because inefficiencies derive from choosing a suboptimal value of $g$ and not from tax-based distortions, it is more instructive to fix $g$.

16. See the Appendix.

17 See the Appendix.

18. A comparison of equations (35) and (33) shows that only when $\varepsilon_{h g}=0$ and $\varepsilon_{\tau y}=-1$, will the effect be identical to the exogenous politics case.

19 It can be shown that a larger response of human capital to government spending (a larger $\left.\varepsilon_{h g}\right)$ implies a larger response of steady-state capital to a change in $\eta$ if $(1-\tau)>\tau \varepsilon_{\tau y}$. This condition restricts the effect of higher government spending on after-tax income to be positive.

20. See Coronado, Fullerton, and Glass [2000] for a discussion of discount rates in the context of Social Security analysis.

21. The uniform distribution is appealing for its tractability, but does not provide a realistic distribution of post-education earnings (which display a log-normal distribution). Thus, an extension for future research is the use of alternative specifications of the ability distribution. 
22. Laitner [2000] argues that $\alpha=0.33$ is consistent with recent United States data.

23. In Appendix Table 1, we investigate the same relationship using a utility function exhibiting constant relative risk aversion (CRRA) rather than the logarithmic form. The constant relative risk aversion form used is

$$
U=\frac{1}{1-\gamma} C_{t}^{1-\gamma}+\frac{1}{1+\delta} \frac{1}{1-\gamma} C_{t+1}^{1-\gamma}
$$

where $\gamma$ is set to 0.5 . Other values of $\gamma$ produced similar results. The results here are largely the same, except that the population decline is immiserizing for a higher cut-off value of $\psi$. Again, we see the decline in tax rate depends on the elasticity $\varepsilon_{\tau a}$, which is larger for smaller values of $\psi$.

24. This nonlinearity comes from the influence of $\psi$ and $\alpha$ on the product $M_{Y} \varepsilon_{h g} \varepsilon_{\tau a}$.

25. The transition paths look similar for a CRRA utility function and the same $\psi$ value.

26. For a discussion of stability in the overlapping generations context, see Azariadis [1993]. 
Table 1. Comparative Steady-State Analysis of Effects of Demographic Transition (percentage change in steady state value)

\begin{tabular}{|c|c|c|c|}
\hline$\psi$ & & $\begin{array}{c}\text { Exogenous } \\
\text { Fiscal Policy }\end{array}$ & $\begin{array}{l}\text { Endogenous } \\
\text { Fiscal Policy }\end{array}$ \\
\hline \multirow{6}{*}{0.32} & y (output per worker) & 16.7 & -3.8 \\
\hline & $\mathrm{k}$ (capital per worker) & 59.7 & 44.4 \\
\hline & $\mathrm{h}$ (human capital per worker) & 0.0 & -21.3 \\
\hline & $\tau($ tax rate $)$ & -14.0 & -90.4 \\
\hline & g (government spending per worker) & 0.0 & -91.0 \\
\hline & $\mathrm{k} / \mathrm{h}$ (capital per unit of $\mathrm{h}$ ) & 59.7 & 83.3 \\
\hline \multirow{6}{*}{0.35} & y (output per worker) & 17.0 & 5.3 \\
\hline & k (capital per worker) & 61.1 & 54.0 \\
\hline & $\mathrm{h}$ (human capital per worker) & 0.0 & -12.7 \\
\hline & $\tau($ tax rate $)$ & -14.1 & -52.8 \\
\hline & $\mathrm{g}$ (government spending per worker) & 0.0 & -50.7 \\
\hline & $\mathrm{k} / \mathrm{h}$ (capital per unit of $\mathrm{h}$ ) & 61.1 & 76.4 \\
\hline \multirow{6}{*}{0.40} & y (output per worker) & 17.6 & 12.4 \\
\hline & k (capital per worker) & 63.6 & 60.9 \\
\hline & $\mathrm{h}$ (human capital per worker) & 0.0 & -5.9 \\
\hline & $\tau($ tax rate $)$ & -14.9 & -28.7 \\
\hline & $\mathrm{g}$ (government spending per worker) & 0.0 & -19.6 \\
\hline & $\mathrm{k} / \mathrm{h}$ (capital per unit of $\mathrm{h}$ ) & 63.6 & 71.0 \\
\hline \multirow{6}{*}{0.50} & y (output per worker) & 19.0 & 23.2 \\
\hline & $\mathrm{k}$ (capital per worker) & 69.4 & 71.4 \\
\hline & h (human capital per worker) & 0.0 & 4.7 \\
\hline & $\tau($ tax rate $)$ & -16.2 & -9.6 \\
\hline & $\mathrm{g}$ (government spending per worker) & 0.0 & 11.6 \\
\hline & $\mathrm{k} / \mathrm{h}$ (capital per unit of $\mathrm{h}$ ) & 69.4 & 63.7 \\
\hline
\end{tabular}

${ }^{a}$ See text for a description of simulation methods used. 


\section{Appendix Table 1. Comparative Steady-State Analysis of Effects of Demographic Transition (percentage change in steady state value)}

\begin{tabular}{llcc}
\hline$\psi$ & & $\begin{array}{c}\text { Exogenous } \\
\text { Fiscal Policy }\end{array}$ & $\begin{array}{c}\text { Endogenous } \\
\text { Fiscal Policy }\end{array}$ \\
\hline \multirow{4}{*}{0.32} & 10.7 & -5.6 \\
& y (output per worker) & 36.0 & 28.8 \\
k (capital per worker) & 0.0 & -18.3 \\
h (human capital per worker) & -10.0 & -73.1 \\
$\tau$ (tax rate) & 0.0 & -74.4 \\
g (government spending per worker) & 36.0 & 55.3 \\
k/h (capital per unit of h) & & \\
& 10.9 & -0.3 \\
y (output per worker) & 36.8 & 31.6 \\
k (capital per worker) & 0.0 & -13.0 \\
h (human capital per worker) & -9.6 & -47.8 \\
$\tau$ (tax rate) & 0.0 & -48.3 \\
g (government spending per worker) & 36.8 & 51.4 \\
k/h (capital per unit of h) & & \\
& 11.3 & 4.8 \\
y (output per worker) & 38.2 & 35.8 \\
k (capital per worker) & 0.0 & -7.8 \\
h (human capital per worker) & -10.0 & -27.9 \\
$\tau$ (tax rate) & 0.0 & -24.2 \\
g (government spending per worker) & 38.2 & 47.2 \\
k/h (capital per unit of h) & & \\
& & 12.2 & 12.6 \\
& y (output per worker) & 41.6 & 41.8 \\
k (capital per worker) & 0.0 & 0.5 \\
h (human capital per worker) & -11.0 & -10.3 \\
$\tau$ (tax rate) & 0.0 & 1.1 \\
g (government spending per worker) & 41.6 & 41.1 \\
k/h (capital per unit of h) & & \\
& & & \\
& & &
\end{tabular}

${ }^{\mathrm{a}}$ See text for a description of simulation methods used. 
Figure 1: Values of $\psi$ and $\alpha$ consistent with higher and lower steadystate income

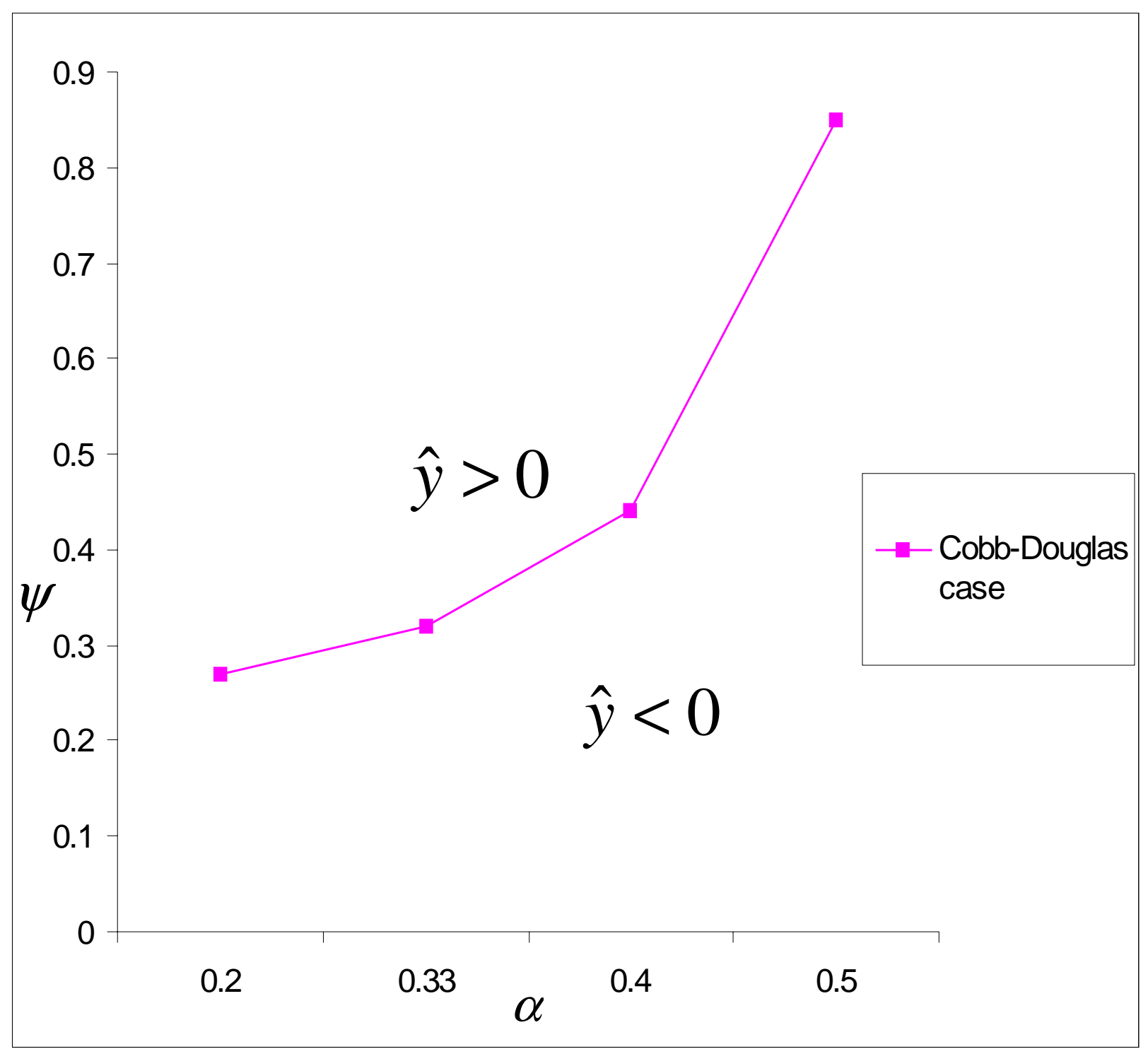



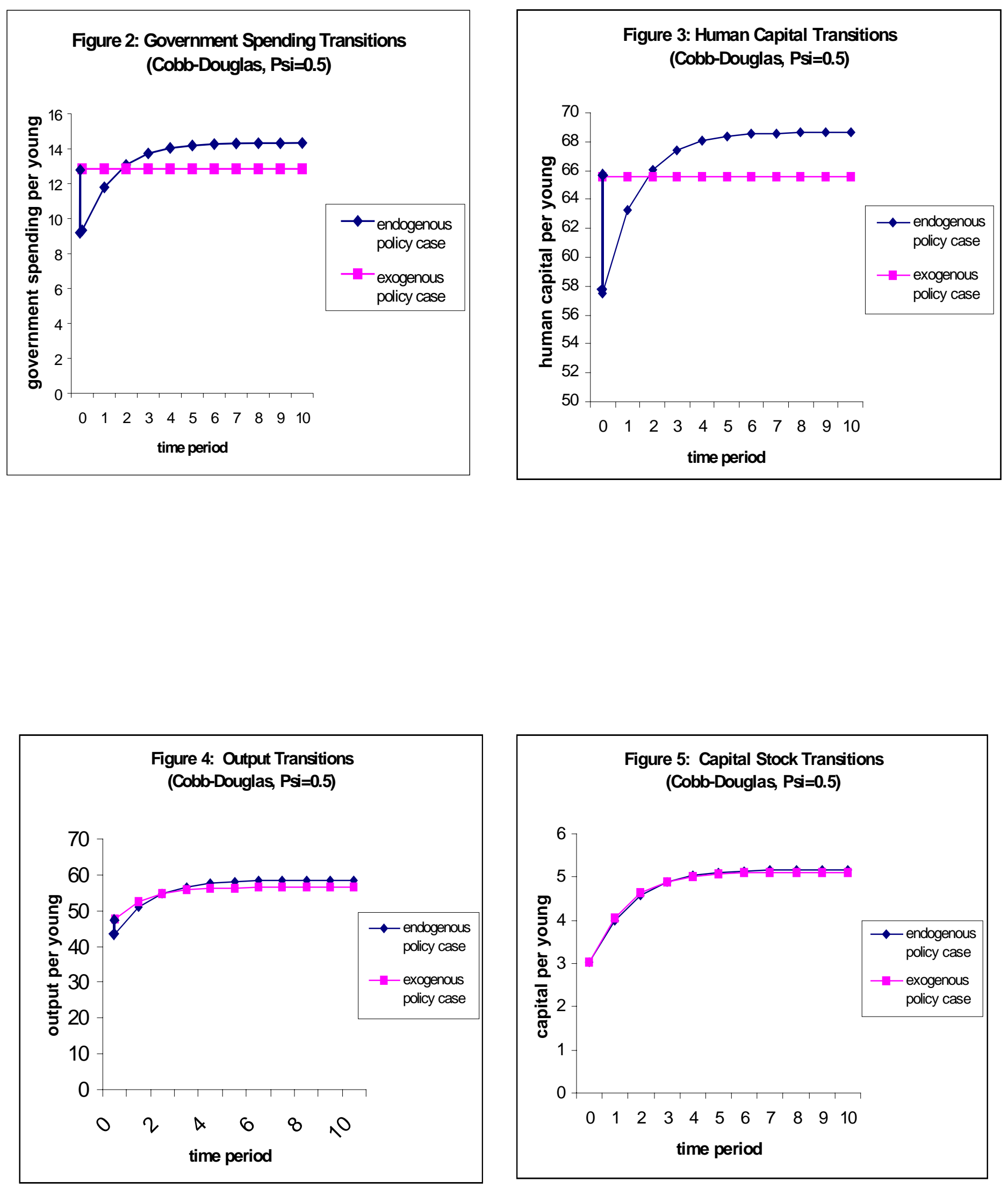


\section{REFERENCES}

Azariadis, C. 1993. Intertemporal Macroeconomics. Cambridge, MA: Blackwell Publishers, pp. 193-204.

Black, D. 1948. "On the Rationale of Group Decision-Making," Journal of Political Economy, 56: 23-34.

Börsch-Supan, A. 1996. "The Impact of Population Ageing on Savings, Investment, and Growth in the OECD Area." In Future Global Capital Shortages: Real Threats or Pure Fiction? Paris: Organisation for Economic Co-operation and Development, pp. 103-141.

Börsch-Supan, A. 1995. "Regional Development, Capital Flows, and Trade Policies in an Ageing Europe." In B. Gahlen, H. Hesse, and H.J. Ramser (eds.), Neue Entwicklungen in der Regionalökonomik. Tübingen: J.C.B. Mohr (Paul Siebeck).

Börsch-Supan, A. 1992. "Population Aging, Social Security Design, and Early Retirement," Journal of Institutional and Theoretical Economics ,148: 533-557.

Bovenberg, A. and C. vanEwijk. 1997. "Progressive Taxes, Equity, and Human Capital Accumulation in an Endogenous Growth Model with Overlapping Generations," Journal of Public Economics, 64: 153-179.

Brueckner, J.K. 1999. "Fiscal Federalism and Capital Accumulation," Journal of Public Economic Theory, 1: 205-224.

Coronado, J.L., D. Fullerton, and T. Gloss. 2000. “The Progressivity of Social Security,” NBER Working Paper No. 7250. Cambridge, MA: National Bureau of Economic Research.

Cutler, D.M., J.M. Poterba, L.M. Sheiner, and L.H. Summers. 1990. “An Aging Society: Opportunity or Challenge?” Brookings Papers on Economic Activity, 1: 1-56.

Diamond, P. 1965. "National Debt in a Neoclassical Growth Model," American Economic Review, 55:1126-1150.

Epple, D. and R.E. Romano. 1996. "Ends Against the Middle: Determining Public Service Provision When There Are Private Alternatives," Journal of Public Economics, 62: 297-325.

Glomm, G. and B. Ravikumar. 1995. "Endogenous Public Policy and Multiple Equilibria," European Journal of Public Economy, 11: 653-662.

Holtz-Eakin, D. 1993. "Demographics, Political Power, and Economic Growth.” In B.L. Wolfe (ed.), On the Role of Budgetary Policy During Economic Transitions, Proceedings of the 48th Congress of the International Institute of Public Finance/Institut International de Finances Publiques, Supplement to Public Finance/Finances Publiques 48:340-365.

Kaganovich, M. and I. Zilcha. 1999. "Education, Social Security and Growth,” Journal of Public Economics, 71: 289-309. 
Laitner, J. 2000. "Simulating the Effect on Inequality and Wealth Accumulation of Eliminating the Federal Gift and Estate Tax," mimeo. Ann Arbor, MI: University of Michigan.

Mankiw, N.G., D. Romer, and D.N. Weil. 1992. "A Contribution to the Empirics of Economic Growth," The Quarterly Journal of Economics, 107: 407-437.

Meijdam, L. and H.A.A. Verbon. 1996. “Aging and Political Decision Making on Public Pensions," Journal of Population Economics, 9: 141-158.

Persson, T. and G. Tabellini (eds.). 1994. "Growth, Distribution, and Politics." In Monetary and Fiscal Policy, Volume 2: Politics. Cambridge, MA: MIT Press, pp. 243-262.

Poterba, J.M. 1997. "Demographic Structure and the Political Economy of Public Education," Journal of Policy Analysis and Management, 61: 48-66.

Romer, T. and H. Rosenthal. 1983. "Voting and Spending: Some Empirical Relationships in the Political Economy of Local Public Finance." In G. Zodrow (ed.), Local Provision of Public Services: The Tiebout Model After Twenty-Five Years. New York: Academic Press, pp. 165-183.

Wright, R. 1996. “Taxes, Redistribution, and Growth,” Journal of Public Economics, 62: $327-$ 338. 